\title{
Monika Janusz-Lorkowska
}

Wydział Dziennikarstwa Informacji i Bibliologii

Uniwersytet Warszawski e-mail: m.janusz-lorko@uw.edu.pl

\section{iGen jako vżytkownik informacii w kontekście kategorii generaci - próba vięcia na podstawie ksiąiki Jean M. Twenge iGen. Sopot: Wydawnictwo Smak Stowa, 2019, ss. 376}

STRESZCZEnIE: Celem artykułu jest wyjaśnienie pojęcia „iGen”, wprowadzonego do literatury naukowej przez amerykańską psycholog J. M. Twenge, przy uwzględnieniu innych terminów dotyczących najmłodszego pokolenia, takich jak Pokolenie Z, Pokolenie Y, Millenialsi, Pokolenie C czy generacja Alfa, a następnie wskazanie, jakie są między nimi różnice i podobieństwa. Ich definicje wymagają uporządkowania i w artykule taka próba została podjęta. Ponadto pojęcie „iGen” analizowane jest w kontekście czytelnika, użytkownika informacji - użytkownika nowych, a także „starych” mediów i adresata komunikacji bibliologicznej. W tym celu przywołane są wyniki dostępnych w Polsce badań na temat użytkowania mediów przez najmłodszego ich odbiorcę/użytkownika.

SŁowA KLuczowe: iGen, Alfa, Pokolenie C, Pokolenie Z, generacja, czytelnictwo dzieci i młodzieży, nowe media, użytkowanie informacji, użytkownik informacji, komunikacja bibliologiczna. 
iGen. Dlaczego dzieciaki dorastajq̨ce w sieci sq mniej zbuntowane, bardziej tolerancyjne, mniej szczęśliwe - i zupełnie nieprzygotowane do dorosłości. I co to oznacza dla nas wszystkich - tak brzmi cały tytuł, wraz z uzupełniającym go podtytułem, najnowszej ${ }^{1}$, wydanej niedawno również w Polsce, książki Jean Marie Twenge, profesor psychologii Uniwersytetu Stanowego w San Diego. Dopisek „i co to oznacza dla nas wszystkich” wskazuje na otwarty i interdyscyplinarny charakter publikacji. I rzeczywiście, badania amerykańskiej psycholog mogą zainteresować zarówno naukowców z jej dziedziny, jak i socjologów, pedagogów, managerów, ekonomistów i medioznawców. 0 dość powszechnym i szerokim zainteresowaniu opisywanymi przez J. M. Twenge zjawiskami świadczy zaproszenie jej do wystąpienia na konferencji naukowej według formatu TEDx i zrealizowania nagrania na temat iGen pod marką TED dla popularnej wśród internautów na całym świecie, niekomercyjnej platformy internetowej TED.com ${ }^{2}$. Trwające nieco ponad siedem minut wystąpienie już podczas nagrywania w Kalifornii, w Monterey, miało kilkusetosobową publiczność, a obecnie na stronach TED obejrzało je blisko 50 tys. internautów ${ }^{3}$. Jej cytowana tutaj książka liczy, łącznie z wstępem i podsumowaniem, dwanaście zróżnicowanych problemowo rozdziałów: 1) Czym jest iGen i skąd to wiemy?, 2) Niedojrzali - powolne dorastanie, 3) W internecie: czas

${ }^{1}$ Dwie wcześniejsze monografie, które Jean M. Twenge wydała w oparciu o własne badania to: The Narcissism Epidemic. Living in the Age of Entitlement, Nowy Jork: Simon \& Schuster, 2009 oraz Generation Me: Why Today's Young Americans Are More Confident, Assertive, Entitled - and More Miserable Than Ever Before, Nowy Jork: Atria Books, 2014.

2 TED jest marką niekomercyjnej amerykańskiej organizacji pozarządowej (tzw. NGO) - Sapling Foundation, a nazwa tej marki to skrót od słów składających się na tytuł pierwszej konferencji naukowej - Technology, Entertainment and Design, zorganizowanej w 1984 r. w stylu do dziś kontynuowanym: spikerzy występują na scenie, wchodząc w interakcje z publicznością, naśladując nieco popularny w USA tzw. stand-up - krótki monolog „na stojąco", ich wystąpienia powinny być perswazyjne i nie dłuższe niż 15-18 minut. Każdorazowo są nagrywane i udostępniane w internecie publiczności na całym świecie. Do wystąpień na konferencjach zapraszani są ludzie nauki, kultury, działacze społeczni, wybitni przedsiębiorcy. Wśród spikerów byli np. Jimmy Wales, Bill Gates, Jane Goodall, Stephen Hawking, Naomi Klein, Edward Snowden, a podczas pierwszej, historycznej konferencji, matematyk polskiego pochodzenia Benoît B. Mandelbrot. Więcej: Our organization / About / TED [online] [dostęp 30 sierpnia 2019]. Dostępny w World Wide Web: https://www.ted.com/about/our-organization.

${ }_{3}$ Wystąpienie J. M. Twenge iGen: The Smartphone Generation [online] [dostęp 30 sierpnia 2019]. Dostępny w World Wide Web: https://www.ted.com/talks/jean_ twenge_igen_the_smartphone_generation_mar_2018. 
spędzany w sieci i w innych mediach, 4) Wirtualni: jestem z tobą, ale nie osobiście, 5) Niespokojni: nowy kryzys zdrowia psychicznego, 6) Niereligijni: religii (i duchowości) mówimy nara!, 7) Odizolowani: bezpieczniej i mniej społecznie, 8) Niepewni dochodów: pracuj, żeby zarabiać, ale nie wydawać, 9) Bez ograniczeń: seks, małżeństwo i dzieci, 10) Inkluzyjni: LGBT, gender i kwestie rasowe w nowej epoce, 11) Niezależni: polityka, 12) Zrozumieć - i ocalić - iGen. Dla dociekań bibliologa i realizowanego w niniejszym artykule tematu najistotniejsze wydają się być rozdziały pierwszy, trzeci, w jakiejś mierze siódmy i jedenasty oraz dwunasty. W zdecydowanej większości do zagadnień z tych właśnie rozdziałów odnoszą się zawarte niżej treści.

\section{Czym/Kim jest iGen?}

Samo wyrażenie iGen w znaczeniu semiotycznym parafrazuje nazwy popularnych na rynku produktów firmy Apple, takich jak iPhone, iPad, iPod. Nazwy te w założeniu producenta mają bezpośrednio wskazywać na fakt, iż urządzenia mogą być w stałym i ciągłym powiązaniu z internetem (internet - skrót od ang. słów „inter-network”, dosłownie „między-sieć” - ogólnoświatowy system połączeń między komputerami, „sieć sieci”"). Sugeruje to litera „i" dodana przed nazwą urządzenia. Podobne skojarzenia ma wywoływać nazwa iGen - skrót od iGeneracji. Według J. M. Twenge iGen to pokolenie ${ }^{5}$ Internetu.

4 A. S. Tanenbaum, Sieci komputerowe, [online] Gliwice 2004, s. 76-87 [dostęp 30 sierpnia 2019]. Dostępny w World Wide Web: on-line: http://pdf.helion.pl/sieci5/ sieci5.pdf.

${ }^{5}$ Należy zwrócić uwagę, że J. M. Twenge używa zwrotów „pokolenie” i „generacja" zamiennie, nadając im takie same znaczenie, tymczasem niektórzy polscy badacze (Bronisław Gołębiowski, Antonina Kłoskowska) rozróżniają te pojęcia. Gołębiowski np. uważa, że „generacja” jest częścią specyficzną „pokolenia”, która konstytuuje się pod wpływem znaczącego przeżycia pokoleniowego. Na tej podstawie wyróżnił np. w Polsce powojennej generację października'56 czy generację Solidarności (zob.: Dynamika aspiracji, studium przemian świadomości społecznej młodzieży polskiej w latach 1945-1975: wybrane zagadnienia, Warszawa 1977). Tymczasem to, co Gołębiowski uznaje za istotne dla wyodrębnienia się generacji (wydarzenie historyczne), inny badacz - Piotr Sztompka przypisuje pokoleniu, które jest zbiorowością ludzi, którzy choć osobno i niezależnie od siebie, doświadczyli takich samych, ważnych wydarzeń historycznych, przeżyli te same 
Urodzeni po 1995 roku, dorastali z telefonem komórkowym, mieli konto na Instagramie, zanim poszli do liceum, i nie pamiętają czasów sprzed Internetu ${ }^{6}$.

Parafrazowanie nazw urządzeń firmy Apple przy opisywaniu tej generacji Autorka tłumaczy następująco:

Najstarsi przedstawiciele iGenu wchodzili w okres nastoletni, kiedy w 2007 roku wprowadzono iPhone'a, a gdy w 2010 roku pojawił się iPad - byli już w liceum. [...] Gdyby to pokolenie miało zostać nazwane na cześć jakiejś rzeczy, mógłby to być właśnie iPhone: ankieta marketingowa z 2015 roku wykazała, że dwie trzecie (!) amerykańskich nastolatków ma to urządzenie"”. Jednocześnie podkreśla, że to nieograniczony dostęp do Internetu od najmłodszych lat jest wyznacznikiem charakteryzującym iGen, a nie marka urządzeń, jakiej to pokolenie do przebywania w internetowej sieci używa. „Nawet jeśli ich smartfona wyprodukował Samsung, a ich tablet to Kindle, ci młodzi ludzie nadal zaliczają się do iGenu - pisze ${ }^{8}$.

Zaznacza, że jest to pokolenie, które telefon komórkowy ma zawsze przy sobie, nawet podczas snu. Telefon jest ostatnią rzeczą, jaką nastolatkowie i młodzi dorośli, urodzeni w roku 1995 lub później, widzą przed snem, i pierwszą, jaką widzą po przebudzeniu. Przy czym rzadko służy im on do rozmawiania.

W moim planie taryfowym mam nieograniczony transfer danych i nielimitowane SMS-y, ale tylko 100 minut rozmów miesięcznie, bo i tak nigdy nie dzwonię?.

sytuacje i reagowali na te same wyzwania, co znalazło wyraz w ich przekonaniu, regułach i wartościach oraz wytworzyło poczucie wspólnego losu (zob.: Socjologia. Analiza społeczna, Kraków 2012, s. 229). W artykule, za J. M. Twenge, oba pojęcia używane są zamiennie.

${ }^{6}$ J. M. Twenge, iGen..., tł. O. Dziedzic, Sopot 2019, s. 10.

7 Tamże.

8 Tamże, s.11.

9 Tamże, s. 60. 
- przyznała jedna z ankietowanych przez Twenge osób. Według badań, które autorka przedstawia w książce „iGen...”, przeciętna amerykańska nastolatka „zagląda” do swojego telefonu ponad osiemdziesiąt razy na dobę.

\section{Metody badań}

Badając różnice między pokoleniami, J. M. Twenge analizuje i porównuje przeprowadzane w USA od kilkudziesięciu lat socjologiczne badania panelowe, ankietujące nastolatki i młodych dorosłych wszystkich stanów: ankietę American Freshman (AF), zarządzaną przez Instytut ds. Badań Szkolnictwa Wyższego, General Social Survey (GSS - ogólna ankieta społeczna), The Youth Risk Behavior Surveillance System (YRBSS - system monitorowania ryzykownych zachowań wśród młodzieży zarządzany przez ośrodki zajmujące się kontrolą i prewencją chorób) i Monitoring the Future (MtF - realizowane przez University of Michigan's Institute for Social Research). Źródła te są rozległe i obejmują dużą próbę - dane są zbierane rokrocznie od tysięcy ankietowanych, którzy anonimowo odpowiadają na setki różnorodnych pytań (wiele z nich jest niezmiennych, odpowiada na nie już kolejne pokolenie Amerykanów). W efekcie Twenge korzysta $\mathrm{z}$ analizy danych, zgromadzonych od ponad 11 milionów respondentów na przestrzeni kilku dekad. Oprócz tego przeprowadza własne badania jakościowe, przede wszystkim metodą IDT - zindywidualizowanego wywiadu pogłębionego, przygotowuje też dla respondentów testy psychologiczne.

J. M. Twenge bada różnice międzypokoleniowe od niemal dwudziestu pięciu lat. Charakteryzowała swoje własne pokolenie - generację $X$ (urodzonych pomiędzy rokiem 1965 a 1979) i porównywała ją z powojennym pokoleniem swoich rodziców - tzw. generacją baby boomers (wyżu demograficznego). Potem przyglądała się narcystycznemu, według opinii wielu badaczy, pokoleniu millenialsów (tym, którzy wchodzili w dorosłość wraz z początkiem nowego milenium) - stąd jej książka Generation $<<M e>>(G e n e r a c j a<<J a>>)$. Wreszcie zaczęła przyglądać się tym, którzy dorastają teraz. Przygotowała ponad 100 wykresów, prezentujących i porównujących dane ankietowe od respondentów z wymienionych wyżej generacji. 
Wykresy pozwalają pomieścić dużą ilość danych na małej przestrzeni, dlatego jeden wykres jest wart więcej niż tysiąc słów. [...]

- przekonuje.

Na podstawie wykresów można się szybko przekonać, jak bardzo iGen wyróżnia się na tle pozostałych pokoleń ${ }^{10}$.

Podkreśla, że największe, diametralne różnice dotyczą przede wszystkim sposobów spędzania wolnego czasu.

\section{iGen a pokolenie Z, Ci Alfa}

Należy tu zaznaczyć, że w literaturze przedmiotu wśród badaczy generacji nie ma zgodności w kwestii pojęć określających kolejne pokolenia. Określenia $X, Y, Z$ (dla kolejnych pokoleń, następujących po sobie od lat 70. ubiegłego wieku do teraz) zastosował m.in. niezależny badacz, ekonomista i futurysta, Michael McQueen m.in. w książce Pokolenie Y. Współistnienie czy współdziałanie. Nowe zasady komunikacji międzypokoleniowej ${ }^{11}$. Za pokolenie $X$ uznał osoby urodzone od połowy lat 60 . do wczesnych lat 80 ., za pokolenie $Y$ urodzonych od wczesnych lat 80 . do późnych 90 . i wreszcie poprzedził wstępną charakterystyką także pokolenie $Z$, które, urodzone w późnych latach 90., w trakcie pisania przez niego książki o „igrekach” kształciło się dopiero w szkołach podstawowych. Według niego „zetki” powinny dojrzewać szybciej niż poprzednie pokolenia nie tylko z powodu tego, że zmienia się język wobec nich używany (na przykład nazywa się ich „małymi ludźmi”, a nie „bobasami”), ale przede wszystkim ze względu na łatwy i powszechny dostęp do nowych technologii cyfrowych od wczesnego dzieciństwa. Zgodnie z powyższym można uznać, że pokolenie $Z$ to ta sama grupa ludzi, którą Twenge nazwała w swych badaniach pokoleniem iGen.

Najbardziej znani (najczęściej cytowani) badacze generacji, amerykańscy historycy - William Strauss i Neil Howe, autorzy tzw. teorii pokoleń

10 Tamże, s. 22.

11 M. McQueen, Pokolenie Y. Współistnienie czy współdziałanie. Nowe zasady komunikacji międzypokoleniowej, tł. L. Grzegrzółka, Warszawa 2016. 
i koncepcji powtarzalności zdarzeń/faz w dziejach zachodniego kręgu kulturowego (zob. książka Generations: The History of America's Future, 1584 to $2069^{12}$ ) i autorzy nazwy millenialsi dla pokolenia $Y^{13}$, za namową internautów pokolenie $Z$ nazywają Homeland Generation - pokoleniem osób „siedzących w domu, w ojczyźnie” z różnych powodów - dostępności do mediów społecznościowych, ale również z powodu poczucia zagrożenia. Tym samym można by przyznać, że mieli rację, pisząc we wcześniejszych pracach, że jest to pokolenie, które będzie w czwartej fazie cyklu pokoleń - fazie kryzysu i poczucia niepewności/zagrożenia. Są to oczywiście osoby urodzone nie wcześniej niż w ostatnich latach 90. ubiegłego wieku, a więc pokolenie iGen.

Z kolei CEFRIO - Międzynarodowy Instytut Badawczy w Quebec City w Kanadzie, jako jeden z pierwszych (w 2009 r.) przygotował raport $\mathrm{z}$ badań na temat wpływu powszechności technologii cyfrowych na osoby urodzone po roku 1995 r. nazywając te osoby, od słów „connect, communicate, change", generacją $C^{14}$. Określenie to przyjęło się i jest obecnie równie często stosowane w literaturze, jak pokolenie Z i iGen.

A generacja Alfa? Według australijskich badaczy - Marka McCrindle i Emily Wolfinger, autorów książki The ABC of XYZ: Understanding the Global Generations ${ }^{15}$, rozpiętość pokoleń „kurczy się”, zajmując teraz przedział czasowy nie w granicach 20-25 lat, ale 15 lat. W przywołanej publikacji zapowiadają, że po 2010 r. rozpocznie się nowe pokolenie i będzie to generacja Alpha. Jego nazwa pochodzi od pierwszej litery alfabetu greckiego i wynika z konieczności odejścia od alfabetu łacińskiego $(X, Y, Z)$, gdyż ten został już wyczerpany przy określaniu wcześniejszych pokoleń. Badacze podkreślają, że Alpha to jedno z pierwszych pokoleń „medialnych”, które bardzo intensywnie doświadcza nowego systemu edukacji opartego na iPadach i e-learningu. Przypuszczają, że Alpha będą dorastać w systemie

12 N. Howe, W. Strauss, Generations: The History of America's Future - 1584 to 2069, Nowy Jork 1992.

${ }^{13}$ N. Howe, W. Strauss, Millennials rising: the next great generation, New York 2000.

14 Raport i badania przygotowane pod przewodnictwem P. Aubé, C. Lamy, Génération C. Les technologies de l'information chez les québécois de 12 à 24 ans [online] [dostęp 9 września 2019]. Dostępny w World Wide Web: https://cefrio.qc.ca/media/1722/generation-c-rapport-synthese.pdf.

${ }_{15}$ M. McCrindle, E. Wolfinger, The of XYZ: Understanding the Global Generations, Sydney 2010. 
Internetu Rzeczy, a nawet Internetu Wszystkich Rzeczy (ang. Internet of Everything). Amerykański ekonomista, profesor Philip Kotler, specjalista od kształcenia w zakresie marketingu, zalicza Internet Rzeczy „do trzeciej fali związanej z rozwojem nowych technologii, które pojawiły się w ciągu ostatnich 50. lat. Pierwsza z nich zautomatyzowała manualne aktywności i doprowadziła do komputerowo wspieranej automatyzacji. Drugi etap rozpoczął się w momencie upowszechnienia Internetu i doprowadził do zaawansowanej koordynacji i integracji działań na poziomie globalnym. Obecna fala spowodowała, że technologia stała się integralną częścią produktów, zamieniając je w komputery"16.

\section{iGen jako czytelnik i użytkownik informaci}

Jak dotąd Alfa, pokolenie będące na ten moment w wieku ok. 9. lat, nie jest jeszcze zbadane i rozpoznane w takim stopniu jak $i G e n$, ale należy się spodziewać, że pokolenie te będzie z powodu cyfrowo-technologicznych doświadczeń i „,internetowego dzieciństwa” łączyło więcej niż iGena z poprzednikami. Jak wspomniano wyżej, badania J. M. Twenge na temat tej generacji mogą być interesujące dla badaczy wielu dziedzin społeczno-humanistycznych, w tym dla różnych subdyscyplin bibliologii. Reprezentanta pokolenia iGen można, a nawet należy, rozpatrywać w kategoriach użytkownika informacji ${ }^{17}$, czytelnika, docelowego adresata bibliologicznej

${ }^{16}$ M. Grodner, IoT - korzyści i wyzwania, [w:] Internet Rzeczy w Polsce, red. P. Kolenda, Warszawa 2016, s. 16 [online] [dostęp 10 września 2019]. Dostępny w World Wide Web: https://iab.org.pl/wp-content/uploads/2015/09/Raport-Internet-Rzeczy-w-Polsce.pdf, za: P. Kotler, J. E. Heppelmann, How smart connected products are transforming competition, Boston 2014.

17 Pojęcie „użytkownika informacji” używane jest w tekście w takim znaczeniu, jakie przypisał temu terminowi brytyjski badacz Tom Wilson, m.in. $\mathrm{w}$ artykule The information user: past, present and future, „Journal of Information Science” 2008, Vol. 34, No. 4, s. 457-464, zaznaczając, iż obecnie użytkownikiem informacji jest każdy, kto przejawia jakiekolwiek zachowania informacyjne, nie tylko osoba korzystająca z formalnych systemów informacyjnych, usankcjonowanych środków przekazu i oficjalnych dokumentów. A więc jest to pojęcie szersze, niż wynikałoby z definicji zawartej w polskiej Encyklopedii współczesnego bibliotekarstwa polskiego (red. Karol Głombiowski, Bolesław Świderski, Helena Więckowska, Wrocław, Warszawa, Kraków, Gdańsk, 1976, s. 302), która mówi, że „użytkownik informacji (odbiorca informacji), to osoba lub instytucja korzystająca z usług służby informacyjnej bibl. lub z działalnościośrodków informacji 
komunikacji. Konkluzje z badań Twenge, analizowane w tak zaproponowanym kontekście, mogą wydawać się niepokojące. Temu, w jaki sposób ta młoda generacja obcuje z mediami i ile czasu na to przeznacza, autorka książki iGen poświęciła cały osobny rozdział. Podsumowując ankiety skonkludowała, że aktualnie nastolatki w USA poświęcają około 17 godzin dziennie na szkołę, sen, odrabianie lekcji i zajęcia pozaszkolne, a czas wolny, niemal cały, spędzają na korzystaniu z tzw. nowych mediów (internetowych). A więc jest to około 6-7 godzin. Dodatkowo około 1,5 do 2 godzin pochłania im oglądanie telewizji.

Oczywiście wygląda to tak, jakby ich doba miała więcej niż 24 godziny

- pisze Twenge.

Bardziej prawdopodobne jest jednak to, że wykonują kilka czynności naraz, a więc esemesują, surfując w sieci, a oglądając telewizję - nierzadko internetową, wrzucają zdjęcia na Instagrama ${ }^{18}$.

Na podstawie badań przeprowadzonych przez Twenge pewne jest, że uczniowie czwartych klas liceum w 2015 r. - a więc już przedstawiciele

[...]". W polskiej literaturze bliższe definicji Toma Wilsona jest krótkie hasło ze Słownika terminologicznego informacji naukowej (red. Maria Dembowska, Wrocław, Warszawa, Kraków, Gdańsk, 1979, s. 119), które wspomina, że „użytkownik informacji to osoba lub zespół osób korzystających z informacji”, oraz termin zawarty W „Słowniku encyklopedycznym informacji, języków i systemów informacyjno-wyszukiwawczych" z 2002 r. pod redakcją Bożeny Bojar mówiący, że użytkownik informacji to „użytkownik będący odbiorcą informacji na wyjściu systemu informacyjno-wyszukiwawczego. Występuje on także w roli nadawcy informacji, przekazując do systemu komunikat w postaci zapytania informacyjnego. W wielu systemach użytkownik sam dokonuje wyszukiwania informacji, samodzielnie określając strategię wyszukiwawczą lub korzystając ze strategii wyszukiwawczej systemu, np. w bibliotekach o wolnym dostępie do półek, w tradycyjnych katalogach i bibliografiach, w Internecie" (s. 288-289). Dziś na gruncie polskiej nauki użytkownika informacji w kontekście różnych podejść badawczych analizuje i definiuje (porządkując inne definicje) m.in. Sabina Cisek, członek Zarządu Polskiego Towarzystwa Informacji Naukowej, autorka tekstu będącego podporą dla niniejszego artykułu - Metodologia badań użytkowników informacji w XXI wieku w świetle anglojęzycznej literatury przedmiotu, „Praktyka i Teoria Informacji Naukowej i Technicznej” 2009, nr 4, s. 3-11 [online] [dostęp 10 września 2019]. Dostępny w World Wide Web: http://www.slideshare. net/sabinacisek/metodologia-badan-uzytkownikow-inf-21-wiek.

18 J. M. Twenge, dz. cyt., s. 62. 
generacji iGen, spędzali online dwa razy więcej czasu niż ich rówieśnicy w 2004 r. („schyłkowi” millenialsi). Na prezentowanych wykresach widać wyraźnie, że czas bycia online gwałtownie wzrasta (wydłuża się) od 2009/2010 r. To moment, w którym do masowej sprzedaży wszedł telefon typu smartfon.

Teoretycznie można by przypuszczać, że przebywanie w cyfrowym świecie, „bycie online”, nie wyklucza pozostawania tradycyjnym czytelnikiem gazet, książek i tradycyjnym widzem telewizji czy kina, tyle, że przy pomocy i za pośrednictwem nowych, cyfrowych nośników i internetowych kanałów. Nic bardziej mylnego. Z badań Twenge wynika, że w opisany wyżej sposób korzystają z nowych mediów millenialsi i pokolenie $X$, a także niektórzy, otwarci medialnie, przedstawiciele baby boomers. Przedstawiciele iGenu są online zaś po to, by czatować przez komunikatory internetowe, prowadzić rozmowy wideo oraz śledzić znajomych i „autoprezentować się" w mediach społecznościowych ${ }^{19}$. Niewielki odsetek z nich - ok. 9\%, większość swojego czasu spędza online, grając w internetowe gry wideo. Internetowe media społecznościowe cieszą się wśród reprezentantów pokolenia iGen zdecydowanie największą popularnością. Wśród nich zaś najpowszechniejsze to Instagram, Twitter, Snapchat, a na Snapchacie funkcja Snapstory (z ang. „story” - opowieść).

Jeśli ćwiczę grę w tenisa albo jestem z przyjaciółmi w którejś ze stołówek, robię filmik albo zdjęcie i dodaję to do mojego Snapstory, po czym dzielę się tym ze znajomymi. Widzę też, co inni wrzucają na swoje Snapstory, czyli co robią ${ }^{20}$.

- mówi jeden z respondentów Twenge. Co ciekawe, badaczka przytacza informacje, z których wynika, że wśród najmłodszego pokolenia na popularności zdecydowanie traci słynny Facebook - historyczne, bo pierwsze ogólnoświatowe medium społecznościowe. Według badań cytowanej przez nią firmy zarządzającej PiperJaffray, jesienią 2016 r. tylko 30\% czternastolatków korzystało z Facebooka przynajmniej raz w miesiącu, w porównaniu z 80\% korzystających z Instagrama i 79\% ze Snapchata. Co istotne, w kontekście niniejszego artykułu, Twenge dowodzi, że iGen

19 Tamże, s. 65-67.
20 Tamże, s. 68. 
prawie w ogóle nie czyta (nie licząc treści umieszczanych pod postami w mediach społecznościowych).

Pod koniec lat siedemdziesiątych XX w. wyraźna większość nastolatków czytała książkę lub czasopismo niemal codziennie, ale około 2015 r. jest to już tylko $16 \%$. Innymi słowy, w porównaniu z iGenem, trzy razy więcej przedstawicieli pokolenia wyżu demograficznego czytało codziennie książkę lub magazyn. Ponieważ pytanie ankietowe wymyślono w latach 70., zanim pojawiły się e-czytniki, nie precyzuje ono formatu książki bądź magazynu, tak więc liczą się też millenialsi czy iGen czytający na Kindlach lub iPadach ${ }^{21}$.

Twenge dowodzi, że iGen nie czyta, ponieważ akcja w książkach nie „toczy się" dość szybko. Drukowane książki nie są w stanie utrzymać uwagi pokolenia nauczonego klikać w następny link albo „przewijać” do następnej strony w ciągu kilku sekund ${ }^{22}$.

Trudno mi się czyta jedną książkę przez dłuższy czas, nie potrafię usiedzieć spokojnie

- przyznaje jedna z respondentek, 12-letnia Harper.

Książki usypiają mnie i są nudne

- mówi inna. Jeszcze inny nastolatek stwierdził:

Mojego tatę nadal interesują całe te książki. Nie zauważył jeszcze, że Internet tak jakby zajął ich miejsce ${ }^{23}$.

\section{Cyfrowa i "czytelnicza" młodziez w Polsce - wybrane badania}

Czy konkluzje z badań przeprowadzonych wśród młodzieży na innym kontynencie mogą okazać się przydatne i być brane pod uwagę przy

\footnotetext{
21 Tamże, s. 71.

22 Tamże.

23 Tamże, s. 71-74.
} 
opracowywaniu strategii komunikacyjnych z nastolatkami i młodymi dorosłymi w Polsce? Raczej tak, ponieważ w wielu punktach pokrywają się z efektami badań dotyczącymi czytelnictwa bądź sposobów spędzania czasu online przez nastolatki w Polsce. I tak, przykładowo przeprowadzane rokrocznie badania Biblioteki Narodowej „Stan czytelnictwa w Polsce" nie śledzą co prawda czytelnictwa wśród nastolatków, ale wyodrębniają wśród badanych grupę wiekową 14-24 lat. Można więc uznać, że rozpatrywanie tej grupy w ciągu ostatnich kilku lat to nic innego, jak rozpatrywanie nawyków czytelniczych generacji iGen. W konkluzjach ujętych w raporcie z badań w roku 2018 widnieje informacja, że grupa ta ma do czytania książek stosunek obojętny - 24\%, raczej ich nie lubi - 22\%, lub bardzo ich nie lubi - 13\%, co w porównaniu do entuzjastów („bardzo lubię czytać książki” - 15\%) stanowi zdecydowaną większość ${ }^{24}$. W 2018 r. 45\% z tej grupy wiekowej nie przeczytało żadnej książki, 22\% jedną lub dwie (przy czym nie wiemy, czy nie były to szkolne lektury) ${ }^{25}$.

Ciekawe są badania związane z czasem spędzanym online przez polskie nastolatki - „Nastolatki 3.0”, przeprowadzone przez NASK (Naukowa i Akademicka Sieć Komputerowa - Państwowy Instytut Badawczy) w 2017 r. $^{26}$. Ich wyniki niemal całkowicie pokrywają się z wynikami badań Twenge.

Wysoka dostępność Internetu w przestrzeniach społecznych (dom, szkoła, miejsca publiczne itd.) koreluje z czasem jaki młodzi użytkownicy Internetu poświęcają na łączność z cyberprzestrzenią

- głosi raport ${ }^{27}$. Zdecydowana większość nastolatków zadeklarowała w tym badaniu, że korzysta z Internetu wiele razy dziennie lub cały czas: w domu $80 \%$, w szkole - 39,2\%, u znajomych 32,4\%, w miejscach

${ }^{24}$ R. Chymkowski, I. Koryś, Stan czytelnictwa w Polsce w 2018 roku. Wstępne wyniki [online] Warszawa 2018, s. 2 [dostęp 2 września 2019]. Dostępny w World Wide Web: https://bn.org.pl/download/document/1553438768.pdf.

25 Tamże, s. 3.

${ }^{26}$ Badania i raport pod kier. W. Kamieniecki, M. Tanaś, Nastolatki 3.0 [online] Warszawa 2017 [dostęp 2 września 2019]. Dostępny w World Wide Web:https://akademia. nask.pl/publikacje/Raport_z_badania_Nastolatki_3_0.pdf.

27 Tamże, s. 9. 
publicznych, gdzie jest dostępna sieć WiFi $-29,7 \%{ }^{28}$. Najbardziej popularnym narzędziem do łączenia się z siecią jest smartfon - polskie nastolatki korzystają z niego, by łączyć się z Internetem średnio 188 minut dziennie, potem laptop - 70 minut dziennie, komputer stacjonarny - 62 minuty dziennie, rzadziej tablet - 25 minut dziennie, konsola do gier - 20,6 minut dziennie, i „inne” - ok. 13 minut dziennie. Razem daje to prawie 6,6 godziny dziennie bycia online. Na długość czasu korzystania z Internetu mocno wpływa płeć nastolatków. Dziewczęta częściej niż chłopcy łączą się z siecią za pomocą: telefonu komórkowego /smartfonu (K - 211,5 minut dziennie, $\mathrm{M}$ - 165,2 minut dziennie), laptopa ( $\mathrm{K}$ - 74,3 minut dziennie, $\mathrm{M}$ - 97,3 minut dziennie), tabletu ( $\mathrm{K}$ - 26,8 minut dziennie, $\mathrm{M}$ - 22,9 minut dziennie). Natomiast chłopcy relatywnie więcej czasu przebywają w sieci przy wykorzystaniu komputera stacjonarnego ( $\mathrm{K}$ - 28,5 minut dziennie, $\mathrm{M}$ - 97,3 minut dziennie) i konsoli do gier ( $\mathrm{K}$ - 13,9 minut dziennie, $\mathrm{M}$ 27,0 minut dziennie) ${ }^{29}$.

Jakie zachowania w tym zakresie będzie przejawiać generacja Alfa? W roku 2015, a więc w roku, kiedy ukazała się książka iGen J. M. Twenge, w Polsce Fundacja Dzieci Niczyje opublikowała raport z ilościowego badania „Korzystanie z urządzeń mobilnych przez małe dzieci w Polsce”.

Badanie przeprowadzone przez Fundację Dzieci Niczyje pokazuje, jak powszechne w Polsce jest korzystanie przez małe dzieci z urządzeń mobilnych, a także stara się przybliżyć charakter tego zjawiska. Jest to pierwsze na gruncie polskim badanie skoncentrowane na najmłodszych dzieciach i zrealizowane na ogólnopolskiej próbie reprezentatywnej dla dzieci w wieku 6 miesięcy - 6,5 lat ${ }^{30}$

- informują badacze we wprowadzeniu do raportu. Do najistotniejszych informacji należą tu następujące konkluzje: aż 64\% dzieci w wieku od 6 miesięcy do 6,5 lat korzysta z urządzeń mobilnych, 25\% z nich - co-

28 Tamże, s. 7.

29 Tamże, s. 10.

${ }^{30}$ A. Bąk, Korzystanie z urządzeń mobilnych przez małe dzieci w Polsce. Wyniki badania ilościowego [online] Warszawa 2015, s. 4 [dostęp 9 września 2019]. Dostępny w World Wide Web: https://fdds.pl/wp-content/uploads/2016/05/Bak_Korzystanie_z_urzadzen_ mobilnych_raport.pdf. 
dziennie. $26 \%$ dzieci posiada własne urządzenie mobilne, 79\% dzieci ogląda na nich filmy, a 62\% gra w gry. Około 63\% dzieci zdarzyło się bawić smartfonem lub tabletem bez konkretnego celu, 69\% rodziców udostępnia dzieciom urządzenia mobilne, kiedy muszą zająć się własnymi sprawami, a 49\% rodziców stosuje to jako rodzaj nagrody dla dziecka.

\section{iGen w komunikaci bibliologicznej}

W kontekście komunikacji bibliologicznej nie sposób pozostawać obojętnym wobec przytoczonych wyżej wyników badań i wynikających z nich konkluzji. Przy czym komunikację bibliologiczną rozumie się tutaj w taki sposób, w jaki mówił o niej Krzysztof Migoń na łamach „Przeglądu Bibliotecznego" już w 1985 r.:

W komunikacji bibliologicznej narzędziem jest książka, jest narzędziem utrwalania przekazu, sposobem prezentacji, sposobem umiejscowienia dzieła literackiego, naukowego, z wszelkimi tego konsekwencjami. Zatem komunikacja bibliologiczna jest jedną z form komunikowania kultury w społeczeństwie ${ }^{31}$.

Już wtedy, w latach 80., przedstawiano w Polsce schematy komunikacji bibliologicznej, a wśród nich propozycję Jerzego Zawiszy, zaprezentowaną w „Studiach o Książce” 32 . Jest to dość skomplikowany schemat uwzględniający ówczesne realia, a więc autora, wydawcę, mecenat, ale i cenzurę, oprócz tego grafika, typografię, dystrybucję, bibliotekarza, krytykę, na końcu czytelnika ${ }^{33}$. Dziś schemat ten, jak i inne, zaproponowane później przez różnych badaczy, są nieaktualne przede wszystkim z tego powodu, że jako narzędzie uznają tylko książkę papierową, drukowaną. Fakt, iż zarówno nośnik treści literackich, jak i kanały jej dystrybucji gwałtowanie zmieniają się, odnotował Sebastian D. Kotuła, poświęcając nowej

${ }^{31}$ K. Migoń, Forum dyskusyjne „Przeglądu Bibliotecznego”, „Przegląd Biblioteczny” 1985, r. 53, z. 3-4, s. 348.

32 J. W. Zawisza, Propozycja schematu komunikacji bibliologicznej, „Studia o Książce” 1980, t. 10, s. 39-58.

33 Tamże, s. 40. 
komunikacji bibliologicznej swoją rozprawę doktorską pt. „Komunikacja bibliologiczna wobec World Wide Web".

Zbliżenie World Wide Web do świata książki wyciska na kulturze książki swój znak. Wdarcie się nowego medium w złożony układ relacji na osi książka-czytelnik jest zapowiedzią głębokich i rozległych zmian. Wszystkich konsekwencji tych zmian nie sposób przewidzieć. Niektóre już się rozpoczęły (masowa digitalizacja), inne są w fazie rozwojowej (masowe publikowanie książek w Internecie), wiele innych dopiero się pojawi. Jedną z nich można dostrzec w procesie wprowadzania książki w obieg społeczny, tj. w komunikacji bibliologicznej. Także forma książki jako symbol wyrażanych przez nią znaczeń pozostaje pod ogromnym wpływem technologii cyfrowych i sieciowych. Odmienność formy (obok treści i funkcji) staje się znakiem innej, ale jednak ekspresji książki elektronicznej i sieciowej, domykającej tradycyjną triadę bibliologicznego postrzegania książki ${ }^{34}$.

Kotuła zaproponował nowy schemat komunikacji bibliologicznej, uwzględniający wszelkie nowe cyfrowe i elektroniczne formy książki (w tym takie jak np. mo-book - książka na urządzenie mobilne), proponując połączenie tradycyjnej komunikacji bibliologicznej (narzędziem której jest książka drukowana) z cyfrową komunikacją bibliologiczną i sieciową komunikacją bibliologiczną (gdzie narzędziem są e-książka i s-książka) ${ }^{35}$. Ich odbiorcą w większości przypadków jest i będzie iGen.

J. M. Twenge oczywiście zauważa nowe formy książki i inne kanały ich dystrybucji i uwzględnia te fakty w swych pytaniach dotyczących czytelnictwa, kierowanych do badanych z grupy iGen. Odkrywa, że ci z respondentów, którzy próbują czytać elektroniczne wersje książki na swoich komputerach lub telefonach, mają problemy z koncentracją.

Esemesowanie/czatowanie i pisanie komentarzy w mediach społecznościowych nie wpływa korzystnie na umiejętność czytania ze zrozumieniem. Może to być częściowo spowodowane problemami

${ }^{34}$ S. D. Kotuła, Komunikacja bibliologiczna wobec World Wide Web [online] Warszawa 2012, s. 4 [dostęp 2 września 2019]. Dostępny w World Wide Web: https://depotuw. ceon.pl/bitstream/handle/item/189/Komunikacja\%20bibliologiczna\%20wobec\%20 World\%20Wide\%20Web.pdf?sequence $=1$.

35 Tamże, s. 175. 
z koncentracją, którym wydają się sprzyjać nowe media. W jednym z badań na laptopach uczniów (Yeykelis i in., 2014) zainstalowano program, który co pięć sekund robił zrzut ekranu. Wykazano, że przełączali się między zadaniami średnio co 90 sekund. Ponad 75\% okienek na ich komputerach było otwartych przez krócej niż minutę. Nie da się tego porównać do siedzenia i czytania godzinami książki ${ }^{36}$.

- konkluduje. Z problemu zdają sobie sprawę również badani w grupie iGen. Jedna z respondentek, kilkunastoletnia Sophia, mówi:

Gdy tylko zaczynam odrabiać lekcje, muszę mieć pod ręką telefon, żeby widzieć, co piszą moi znajomi...To tak, jakby ktoś cały czas klepał cię w ramię, a ty po prostu musisz się odwrócićc ${ }^{37}$.

Twenge zauważa, że ogromny spadek czytelnictwa w badanej przez nią grupie wiekowej powinien być wyzwaniem dla szerokiego grona zainteresowanych - rodziców, nauczycieli, wydawców. Docenia, iż wielu amerykańskich wydawców zaczyna publikować bardziej interaktywne e-booki.

Jako pracownik uniwersytecki i autorka lub współautorka trzech podręczników uważam, że musimy pójść nawet dalej. iGen potrzebuje podręczników, w których będzie więcej zadań interaktywnych, takich jak udostępnianie filmików wideo czy wypełnianie kwestionariuszy, ale też podręczników, które będą krótsze i napisane bardziej potocznym stylem ${ }^{38}$.

\section{Jak wspótpracować z iGen}

Niewykluczone, że motywowani nie tylko społeczną troską, ale i potrzebami ekonomicznymi, producenci książek, ale i np. strategicznych gier komputerowych wymagających przeczytania skomplikowanych instrukcji ze zrozumieniem, będą podejmować coraz więcej rozmaitych prób skutecznego dotarcia z treścią literacką do generacji iGen. Nie bez powodu cyfrowymi upodobaniami młodych interesują się cytowani wyżej ekono-

\footnotetext{
${ }^{36}$ J. M. Twenge, dz. cyt., s. 75-76.

37 Tamże, s. 66.

38 Tamże, s. 76.
} 
miści i eksperci ds. marketingu, jak McQueen, Kotler, Heppelmann, którzy zawodowo doradzają wydawcom i biznesmenom.

Patrząca na przedstawicieli różnych generacji z perspektywy pracodawcy i kierownika pracowniczego zespołu - prof. Anna Lipka z Uniwersytetu Ekonomicznego w Katowicach, przestrzega jednak przed stereotypowym podejściem do jednostki poprzez postrzeganie jej wyłącznie poprzez pryzmat cech charakterystycznych dla jej generacji. Nie dzieli powszechnych obaw dotyczących najmłodszego pokolenia, wychodząc z założenia, iż nadszedł koniec epoki gospodarki opartej na wiedzy, a zaczyna się czas gospodarki kreatywnej ${ }^{39}$. W postrzeganiu generacji iGen (pokolenia $Z$ ) jest pozytywna. W swych badaniach porównała ją z poprzednimi generacjami i zauważyła, że w niektórych obszarach iGen jest notowany wyżej niż pokolenie $X i Y$. Są to obszary takie jak globalny styl myślenia, umiejętność stosowania strategii tworzenia, umiejętność prezentacji i upowszechniania treści oraz ogromna zdolność do generowania nowej wiedzy ${ }^{40}$.

Respondenci przynależni generacji $Z$ są bardzo wrażliwi na punkcie komputeryzacji, traktując cyfrową demencję (określenie zaproponowane w 2012 r. przez M. Spitzera) jako przypisywany im negatywny stereotyp ${ }^{41}$.

Według Twenge, autorki książki iGen, największą rolę w uchronieniu najmłodszej generacji przed uzależnieniem od cyfrowego i wirtualnego świata oraz negatywnymi konsekwencjami tego uzależnienia, mają rodzice. Nauczyciele, wydawcy, producenci itp. mogą szukać nowych dróg komunikacji i doskonalić/rozbudowywać narzędzia tej komunikacji (np. sieciowa komunikacja bibliologiczna i interaktywne książki), ale dla świata „w realu” (rzeczywistego) mogą „uchować” przedstawicieli Pokolenia $Z$ (a teraz i Alfa) tylko ich bliscy i rodzice. Pisze o tym w rozdziale „Zrozumieć i ocalić iGen”. Podpowiada, jak to zrobić, dając proste rady typu ograniczanie dzieciom i nastolatkom czasu przebywania w Internecie, blokowanie niektórych stron www, w tym społecznościowych, kupienie tradycyjnego budzika, by telefon nie był tym przedmiotem, który dziecko bierze do ręki jako pierwszy po przebudzeniu. Jako psycholog

39 A. Lipka, Percepcja różnic generacyjnych - interpretacje i wnioski dla kierujących kreatywnym zespołami, „Edukacja Ekonomistów i Menedżerów” 2017, nr 3, s. 141-154.

40 Tamże, tabela 1, s. 145-146.

41 Tamże, s. 148-149. 
przestrzega przed konsekwencjami oderwania od realnego świata, które są dużo poważniejsze niż powszechny spadek czytelnictwa. To brak umiejętności w nawiązywaniu prawdziwych, społecznych relacji, zagubienie, samotność, strach, izolacja - nowy, potężny kryzys w dziedzinie zdrowia psychicznego.

\section{Bibliografia}

Aubé Philippe, Lamy Catherine, Génération C. Les technologies de l'information chez les québécois de 12 à 24 ans [online] [dostęp 9 września 2019]. Dostępny w World Wide Web: https://cefrio.qc.ca/media/1722/generation-c-rapport-synthese.pdf.

Bąk Agnieszka, Korzystanie z urządzeń mobilnych przez małe dzieci w Polsce. Wyniki badania ilościowego, Warszawa: Fundacja Dzieci Niczyje, 2015.

Chymkowski Roman, Koryś Izabela, Stan czytelnictwa w Polsce w 2018 roku. Wstępne wyniki, Biblioteka Narodowa, Warszawa 2018 [online] [dostęp 2 września 2019]. Dostępny w World Wide Web: https://bn.org.pl/download/document/1553438768.pdf.

Cisek Sabina, Metodologia badań użytkowników informacji w XXI wieku w świetle anglojęzycznej literatury przedmiotu, „Praktyka i Teoria Informacji Naukowej i Technicznej" 2009, nr 4, s. 3-11 [online] [dostęp 2 września 2019]. Dostępny w World http://www.slideshare.net/sabinacisek/metodologia-badan-uzytkownikow-inf-21-wiek.

Encyklopedia współczesnego bibliotekarstwa polskiego, red. K. Głombiowski,

B. Świderski, H. Więckowska, Wrocław, Warszawa, Kraków, Gdańsk 1976.

Grodner Marta, IoT - korzyści i wyzwania, [w:] Internet Rzeczy w Polsce, red. P. Kolenda, Warszawa: IAB Polska, 2016 [online] [dostęp 10 września 2019]. Dostępny w World Wide Web: https://iab.org.pl/wp-content/uploads/2015/09/Raport-Internet-Rzeczy-w-Polsce.pdf.

Howe Neil, Strauss William, Millennials rising: the next great generation, New York: Vintage Books, 2000.

Kamieniecki Wojciech, Tanaś Maciej, Nastolatki 3.0, Warszawa: NASK, 2017 [online] [dostęp 02 września 2019]. Dostępny w World Wide Web: https:// akademia.nask.pl/publikacje/Raport_z_badania_Nastolatki_3_0.pdf.

Kiedrowicz Grzegorz, Pokolenie iGEN wkracza w świat dorosłych, „Edukacja Technika - Informatyka" 2018, nr 3(25), s. 201-223. 
Kotuła Sebastian, Komunikacja bibliologiczna wobec World Wide Web, Warszawa: Uniwersytet Warszawski, 2012.

Lipka Anna, Percepcja różnic generacyjnych - interpretacje i wnioski dla kierujących kreatywnym zespołami, „Edukacja Ekonomistów i Menedżerów” 2017, nr 3, s. 141-154.

McCrindle Mark, Wolfinger Emily, The of XYZ: Understanding the Global Generations, Sydney: UNSW Press, 2010.

McQueen Michael, Pokolenie Y. Współistnienie czy współdziałanie. Nowe zasady komunikacji międzypokoleniowej, tł. Liliana Grzegrzółka, Warszawa 2016. Migoń Krzysztof, Forum dyskusyjne „Przeglądu Bibliotecznego”, „Przegląd Biblioteczny" 1985, r. 53, z. 3-4, s. 327-364.

Słownik encyklopedyczny informacji, języków i systemów informacyjno-wyszukiwawczych, red. W. Babik, B. Bojar, Warszawa 2002.

Słownik terminologiczny informacji naukowej, red. M. Dembowska, Wrocław, Warszawa, Kraków, Gdańsk 1979.

Twenge, Jean M., iGen. Dlaczego dzieciaki dorastające w sieci sq mniej zbuntowane, bardziej tolerancyjne, mniej szczęśliwe - i zupełnie nieprzygotowane do dorosłości. I co to oznacza dla nas wszystkich, tł. O. Dziedzic, Sopot 2019. Wilson Tom, The information user: past, present and future, „Journal of Information Science" 2008, Vol. 34, No. 4, s. 457-464.

Zawisza Jerzy, Propozycja schematu komunikacji bibliologicznej, „Studia o Książce” 1980 , t. 10 , s. $39-58$.

\section{iGen as a user of information in a generation perspective. Referring to the Jean M. Twenge's book iGen, Sopot: Smak Stowa Publishing House, 2019, p. 376}

AвSTRACT: The purpose of the article is to explain the concept of „iGen” introduced to scientific literature by American psychologist J. M. Twenge. This was done by taking into account other terms related to the youngest generation, such as Generation Z, Generation Y, Millennials, Generation C or Generation Alfa. Then the differences and similarities between them were pointed out. The definitions of the above concepts need to be ordered and such attempt was made in this article. In addition, the concept of „iGen” is analyzed in the context 
of the reader, the user of information derived from new media and "old" media and the addressee of bibliological communication. For this purpose, the results of studies available in Poland on the use of media by the youngest recipient/ user are recalled.

KEYWORDS: iGen, Alpha, Generation C, Generation Z, children's and youth reading, new media, use of information, information user, bibliological communication. 